\title{
12. DATA REPORT: TRACE ELEMENT GEOCHEMISTRY OF LEG 142 BASALTS BY INSTRUMENTAL NEUTRON ACTIVATION ANALYSIS ${ }^{1}$
}

\author{
James F. Allan ${ }^{2}$
}

\begin{abstract}
During Leg 142 , two units of moderately evolved basalt were recovered from the East Pacific Rise axis at $9^{\circ} 30^{\prime} \mathrm{N}$. Instrumental neutron activation analysis of seven samples from these units shows them to be light rare-earth-element (REE)depleted, normal mid-ocean ridge basalt, with $(\mathrm{La} / \mathrm{Sm})_{\mathrm{N}}$ of $0.52-0.56$, flat chondrite-normalized medium-to-heavy rare earth patterns, and slight negative europium anomalies. Unit 2 contains slightly higher amounts of REE and $\mathrm{Hf}$ and lower amounts of $\mathrm{Cr}$ than Unit 1, with both units similar in composition to the most-evolved samples previously collected from this section of the ridge crest.
\end{abstract}

\section{INTRODUCTION}

Drilling and coring at mid-ocean ridge spreading centers has been a long-standing goal in the earth science community. Fundamental petrological, hydrothermal, geochemical, structural, and geophysical problems of oceanic crustal formation can only be answered by direct observation and recovery of core. Site 864 , located at $9^{\circ} 30^{\prime} \mathrm{N}$ on the East Pacific Rise (EPR), represented the initial attempt in a longrange plan to core the entire crustal section at the EPR. The principal scientific goal of Leg 142 was to core $100 \mathrm{~m}$ into the uppermost crust of this fast-spreading center $(11 \mathrm{~cm} /$ year; Klitgord and Mammerickx, 1982). Though coring results fell well short of expectations (drilling and coring penetrated only $15 \mathrm{~m}$ into the crust at Site 864 , Holes $864 \mathrm{~A}$ and $\mathrm{B}$ ), the samples recovered represent the initial benchmark in the suite of materials to be recovered at this site, and so are of crucial importance in establishing the crustal characteristics and magmatic processes operating at this portion of the EPR. This report presents the results of instrumental neutron activation analysis (INAA) of seven samples from Site 864 .

Samples collected at the axial ridge crest of the EPR between the Clipperton Fracture Zone $\left(\approx 10^{\circ} \mathrm{N}\right)$ and the offset spreading center at $9^{\circ} 03^{\prime} \mathrm{N}$ are remarkably homogenous in composition, with almost all representing moderately evolved, incompatible-element-depleted normal mid-ocean ridge basalt (N-MORB) (Batiza and Niu, 1992; Langmuir et al., 1986; Allan et al., 1989). X-ray fluorescence studies during Leg 142 (Storms, Batiza, et al., 1993) and INAA analytical results reported here reveal that the recovered samples from Holes $864 \mathrm{~A}$ and $864 \mathrm{~B}$ share these geochemical characteristics.

\section{SAMPLE DESCRIPTION}

Site 864 was located within the axial summit caldera on a flat, relatively unfissured lava flow at about $2581 \mathrm{~m}$ depth. Samples from Holes 864A and 864B took the form of bit recoveries, "junk basket" recoveries resulting from cleaning out of the holes, and cores. Details

\footnotetext{
${ }^{1}$ Batiza, R., Storms, M.A., and Allan, J.F. (Eds.), 1995. Proc. ODP, Sci. Results, 142: College Station, TX (Ocean Drilling Program).

${ }^{2}$ Ocean Drilling Program and Department of Geology, Texas A\&M University, College Station, TX 77845, U.S.A.
}

of sample recovery are given in Storms, Batiza, et al. (1993). Two lithological units were defined, based on slight differences in composition and mineralogy. Unit 1, about 7-12 m thick, consists of glassy, aphyric basalt comprised of massive and sheet/lobate flows, sparse phenocrysts of euhedral plagioclase, and very rare phenocrysts of euhedral clinopyroxene. Unit 2 , of unknown thickness, is microcrystalline, aphyric to sparsely phyric, and contains up to $2 \%$ euhedral, glomerocrystic plagioclase phenocrysts and very rare, euhedral olivine. Further petrographic descriptions are given in Storms, Batiza, et al. (1993). Both Units 1 and ${ }^{\wedge}$ are moderately evolved N-MORBs, with average $\mathrm{Mg} /\left(\mathrm{Mg}+\mathrm{Fe}^{2+}\right)$ of 0.581 and 0.565 , respectively (Storms, Batiza, et al., 1993), and compositions within the range previously reported by Batiza and Niu (1992) for samples from this section of the ridge.

\section{ANALYTICAL METHODS}

Analyses were obtained on splits of powders analyzed by X-ray fluorescence (XRF) during Leg 142 (Storms, Batiza, et al., 1993). Samples were prepared initially on ship by crushing clean, washed rock in teflon vessels by a press, followed by pulverization in an alumina ceramic barrel by a SPEX Shatterbox. Most of these powders were derived from clean, picked, relatively aphyric glass, with other powders originating from fresh, relatively aphyric, fine-grained samples; thus, they should closely approximate the erupted magmatic composition (e.g., Byerly et al., 1976). BAS142 represents an inhouse standard derived from basaltic glass of Unit 1 .

The INAA analyses were conducted at Texas A\&M University using an on-campus TRIGA reactor for irradiation and counting facilities in the Center for Chemical Characterization for analysis. The NBS standard flyash SRM1633A was used as the multiple-element standard (Korotev, 1987), with its Tb content corrected to $2.53 \mathrm{ppm}$ (L. Korotev, pers. comm., 1991). Samples were stacked three levels high in the cans used for sample irradiation. To compensate for flux variation in the reactor, each layer was individually calibrated to three samples of the SRM1633A flyash. Fifty-milligram samples were irradiated for 14 hours and counted for 6 hours apiece at 9 to 12 and 40 to 43 days using lead-shielded, Ortec coaxial intrinsic germanium detectors. These detectors have efficiencies of $22 \%$ to $24 \%$ relative to a $3 \times 3$-inch $\mathrm{NaI}$ detector crystal at a distance of $25 \mathrm{~cm}$, with resolutions of 1.64 to $1.68 \mathrm{KeV}$ at FWHM of the $1332 \mathrm{KeV}$ line of ${ }^{60} \mathrm{Co}$. Dead-time was kept below $5 \%$ during counting. Spectral anal- 
Table 1. Analyses of the standard AGV-1.

\begin{tabular}{lccccccc}
\hline & & & & & & \multicolumn{2}{c}{ AGV-1 } \\
& AGVI-1 & AGV1-2 & AGV1-3 & Average & Std dev & accepted & Std dev \\
\hline $\mathrm{Na}(\%)$ & 3.04 & nd & 3.20 & 3.12 & 0.11 & 3.16 & 0.08 \\
$\mathrm{Fe}(\%)$ & 4.57 & 4.65 & 4.83 & 4.68 & 0.13 & 4.73 & 0.12 \\
$\mathrm{Sc}$ & 11.6 & 12.0 & 12.2 & 11.9 & 0.3 & 12.2 & 1.1 \\
$\mathrm{Cr}$ & 13 & 11 & 12 & 12 & 1 & 10 & 2 \\
$\mathrm{Co}$ & 15.2 & 15.5 & 15.9 & 15.5 & 0.4 & 15.3 & 1.6 \\
$\mathrm{Ni}$ & & 24 & & 16 & 3 & & \\
$\mathrm{Zn}$ & 89 & 87 & 93 & 90 & 3 & 88 & 9 \\
$\mathrm{Rb}$ & 64 & 59 & 71 & 65 & 6 & 67.3 & 0.9 \\
$\mathrm{Sr}$ & 668 & 745 & 725 & 713 & 40 & 662 & 9 \\
$\mathrm{Ba}$ & 1164 & 1166 & 1160 & 1163 & 3 & 1226 & 17 \\
$\mathrm{La}$ & 38.2 & 38.6 & 38.9 & 38.6 & 0.4 & 38 & 3 \\
$\mathrm{Ce}$ & 68.3 & 70.4 & 72.3 & 70.3 & 2.0 & 67 & 5 \\
$\mathrm{Sm}$ & 5.98 & 6.22 & 5.94 & 6.05 & 0.15 & 5.9 & 0.4 \\
$\mathrm{Eu}$ & 1.52 & 1.63 & 1.63 & 1.59 & 0.06 & 1.64 & 0.10 \\
$\mathrm{~Tb}$ & 0.74 & 0.61 & 0.67 & 0.67 & 0.07 & 0.70 & 0.10 \\
$\mathrm{Yb}$ & 1.56 & 1.68 & 1.62 & 1.62 & 0.06 & 1.72 & 0.19 \\
$\mathrm{Lu}$ & 0.25 & 0.24 & 0.24 & 0.24 & 0.01 & 0.27 & 0.03 \\
$\mathrm{Hf}$ & 5.34 & 5.31 & 5.43 & 5.36 & 0.06 & 5.1 & 0.4 \\
$\mathrm{Ta}$ & 0.87 & 0.89 & 0.84 & 0.87 & 0.02 & 0.90 & 0.09 \\
$\mathrm{Th}$ & 6.27 & 6.32 & 6.59 & 6.39 & 0.17 & 6.5 & 0.5 \\
$\mathrm{U}$ & 1.91 & 2.09 & 1.57 & 1.86 & 0.26 & 1.92 & 0.15 \\
\hline
\end{tabular}

Notes: Std dev = standard deviation. Accepted values for AGV-1 from Gladney et al. (1992).

ysis and peak-height evaluation was made using a software package by Nuclear Data, with U- and Th-series overlap and interference corrections done by hand (Landsberger and Simsons, 1987; Landsberger, 1986; Glascock et al., 1986).

To ensure historical run-to-run consistency, a sample of the international standard AGV-1 was run in each layer, with results given in Table 1. These results show excellent overall agreement with accepted values (Gladney et al., 1992); Ba is the only element whose concentration differs within analytical error.

\section{RESULTS}

Analytical results are presented in Table 2, with chondrite-normalized REE concentrations plotted in Figure 1. Unit 1 samples are uniform in their composition, as was noted with XRF-derived major and trace element analyses (Storms, Batiza, et al., 1993); the analytical standard deviations given for the Unit 1 samples in Table 2 are

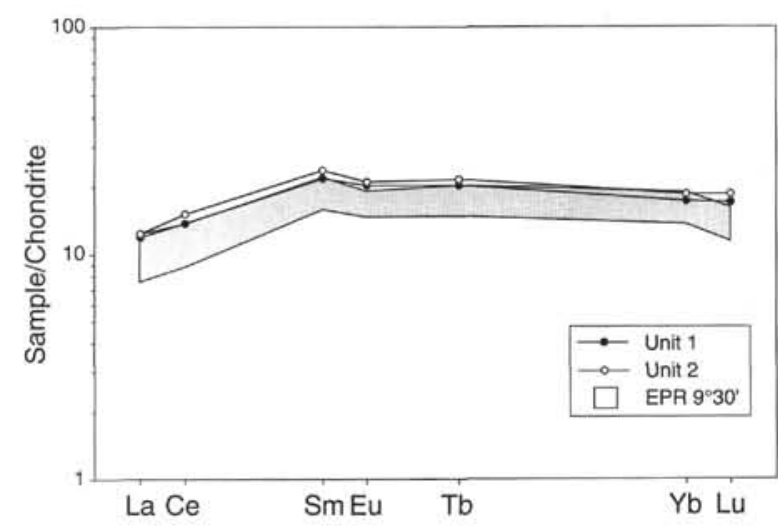

Figure 1. Comparison of the average REE contents of Leg 142 units with those of N-MORB samples collected previously from the EPR in the region of $9^{\circ} 30^{\prime} \mathrm{N}$ (EPR sample data shown by shaded area; data from Batiza and Niu, 1992). Chondrite normalizations follow Haskin et al. (1968). Slight reported differences in Lu contents between the two data sets may reflect differences in analytical procedure regarding the determination of INAA peak backgrounds.

probably an excellent indication of the actual analytical uncertainty for the entire analysis procedure. Ta is curiously high in the Unit 2 Sample 142-864A-4Z1, Piece 2 (Table 2), perhaps reflecting contamination in this whole-rock sample from drillbit tungsten carbide teeth. In general, the INAA measurements match well with the shipboard $\mathrm{XRF}$ analyses, the exception being $\mathrm{Zn}$ (the average shipboard XRF $\mathrm{Zn}$ for samples from Units 1 and 2 are 92 and $93 \mathrm{ppm}$, respectively).

The two units overlap in composition in most elements, with Unit 2 containing slightly higher REE and Hf and lower $\mathrm{Cr}$. These elemental variations are consistent with other XRF-derived major and trace element data that suggest that Unit 2 is slightly more evolved than Unit 1 (Storms, Batiza, et al., 1993). Th, U, Rb, and Ba are all below the analytical detection limits $(<0.18,<0.14,<9$, and $<30 \mathrm{ppm}$, respectively). All Leg 142 samples are substantially depleted in the light REE, with flat chondrite-normalized medium-to-heavy REE patterns (Fig. 1; Table 2). Like other samples from this section of the EPR (Batiza and Niu, 1992), they contain slight negative europium anomalies (average Eu/Eu* is 0.96 for Unit 1 and 0.92 for Unit 2 ) that

Table 2. Analyses of Leg 142 samples.

\begin{tabular}{|c|c|c|c|c|c|c|c|c|c|c|c|}
\hline $\begin{array}{l}\text { Hole: } \\
\text { Section: } \\
\text { Interval }(\mathrm{cm}) \text { or piece number: } \\
\text { Unit: } \\
\text { Comments: }\end{array}$ & $\begin{array}{l}864 \mathrm{~A} \\
1 \mathrm{M} 2 \\
0-35 \\
1 \\
\text { Glass }\end{array}$ & $\begin{array}{c}864 \mathrm{~A} \\
1 \mathrm{M} 3 \\
0-100 \\
1 \\
\text { BAS142 glass std }\end{array}$ & $\begin{array}{c}864 \mathrm{~A} \\
1 \mathrm{M} 5 \\
50-100 \\
1 \\
\text { Glass } \\
\end{array}$ & $\begin{array}{c}864 \mathrm{~A} \\
1 \mathrm{M} 6 \\
0-75 \\
1 \\
\text { Glass }\end{array}$ & $\begin{array}{c}864 \mathrm{~B} \\
2 \mathrm{~W} 1 \\
16-18 \\
1 \\
\text { Whole rock }\end{array}$ & $\begin{array}{c}1 \\
\text { Average } \\
\end{array}$ & $\begin{array}{c}1 \\
\text { Std dev } \\
\end{array}$ & $\begin{array}{c}864 \mathrm{~A} \\
4 \mathrm{Z} 1 \\
\text { Piece } 2 \\
2 \\
\text { Whole rock } \\
\end{array}$ & $\begin{array}{c}864 \mathrm{~A} \\
5 \mathrm{ZI} \\
24-30 \\
2 \\
\text { Whole rock }\end{array}$ & $\begin{array}{c}2 \\
\text { Average }\end{array}$ & $\operatorname{Std}^{2} \mathrm{dev}$ \\
\hline $\mathrm{Na}(\%)$ & 1.93 & 2.02 & 1.93 & 2.01 & 2.03 & 1.98 & 0.04 & 1.95 & 2.03 & 1.99 & 0.06 \\
\hline $\mathrm{Fe}(\%)$ & 8.32 & 8.23 & 7.83 & 8.36 & 8.12 & 8.17 & 0.19 & 8.28 & 8.53 & 8.41 & 0.18 \\
\hline $\mathrm{Sc}$ & 44.6 & 44.2 & 42.2 & 44.8 & 44.0 & 44.0 & 0.9 & 43.3 & 43.9 & 43.6 & 0.4 \\
\hline $\mathrm{Cr}$ & 239 & 249 & 227 & 241 & 241 & 239 & 7 & 195 & 167 & 181 & 19 \\
\hline Co & 45.5 & 45.6 & 42.4 & 45.0 & 43.0 & 44.3 & 1.3 & 44.6 & 43.2 & 43.9 & 1.0 \\
\hline $\mathrm{Ni}$ & 66 & 57 & 82 & 75 & 86 & 73 & 11 & 61 & 50 & 55 & 8 \\
\hline $\mathrm{Zn}$ & 108 & 121 & 111 & 106 & 111 & 111 & 5 & 112 & 117 & 114 & 4 \\
\hline $\mathrm{La}$ & 3.76 & 4.05 & 3.80 & 3.84 & 4.23 & 3.94 & 0.18 & 4.02 & 4.12 & 4.07 & 0.07 \\
\hline $\mathrm{Ce}$ & 12.3 & 12.0 & 11.2 & 12.5 & 12.4 & 12.1 & 0.5 & 13.3 & 13.3 & 13.3 & 0 \\
\hline $\mathrm{Sm}$ & 3.68 & 4.12 & 3.84 & 3.86 & 4.13 & 3.93 & 0.17 & 4.13 & 4.37 & 4.25 & 0.17 \\
\hline $\mathrm{Eu}$ & 1.42 & 1.42 & 1.33 & 1.42 & 1.38 & 1.39 & 0.04 & 1.42 & 1.46 & 1.44 & 0.03 \\
\hline $\mathrm{Tb}$ & 1.01 & 0.89 & 0.95 & 0.96 & 0.91 & 0.94 & 0.04 & 0.93 & 1.07 & 1.00 & 0.10 \\
\hline $\mathrm{Yb}$ & 3.24 & 3.55 & 3.32 & 3.48 & 3.60 & 3.44 & 0.14 & 3.61 & 3.76 & 3.69 & 0.11 \\
\hline Lu & 0.61 & 0.55 & 0.56 & 0.56 & 0.60 & 0.58 & 0.02 & 0.53 & 0.71 & 0.62 & 0.13 \\
\hline $\mathrm{Hf}$ & 2.90 & 2.95 & 2.82 & 3.07 & 2.90 & 2.93 & 0.08 & 3.32 & 3.22 & 3.27 & 0.07 \\
\hline $\mathrm{Ta}$ & 0.21 & 0.23 & 0.21 & 0.22 & 0.16 & 0.21 & 0.02 & 0.65 & 0.20 & 0.43 & 0.32 \\
\hline$(\mathrm{La} / \mathrm{Sm})_{\mathrm{N}}$ & 0.56 & 0.54 & 0.54 & 0.55 & 0.56 & 0.55 & 0.01 & 0.53 & 0.52 & 0.53 & 0.01 \\
\hline
\end{tabular}

Notes: Samples in ppm; $\mathrm{Na}$ and $\mathrm{Fe}$ in wt\%. Std dev = standard deviation. (La/Sm), represents the chondritic normalization of La/Sm $(\mathrm{Haskin}$ et al., 1968). Average counting uncertainties (in ppm, unless noted) are: $\mathrm{Na}, 0.03 \% ; \mathrm{Fe}, 0.02 \% ; \mathrm{Sc}, 0.04 ; \mathrm{Cr}, 2 ; \mathrm{Co}, 0.1 ; \mathrm{Ni}, 11 ; \mathrm{Zn}, 3 ; \mathrm{La}, 0.06 ; \mathrm{Ce}, 0.5 ; \mathrm{Sm}, 0.01 ; \mathrm{Eu}, 0.03 ; \mathrm{Tb}, 0.06 ; \mathrm{Yb}, 0.05 ; \mathrm{Lu}, 0.01 ; \mathrm{Hf}, 0.12 ; \mathrm{and}$ $\mathrm{Ta}, 0.04$. 
may be related to plagioclase fractionation. Overall, they represent N-MORB compositions (Sun and McDonough, 1989) and are similar in nature to the more evolved samples previously collected from this area of the ridge crest (Fig. 1; Batiza and Niu, 1992).

\section{ACKNOWLEDGMENTS}

I thank the SEDCO BP471 crew, the ODP engineers, and the ODP technical staff for their Herculean efforts to recover these samples. I am especially grateful to Rodey Batiza, who took me on as a green post-doc in 1985 and introduced me to the joys of EPR MORB petrology.

\section{REFERENCES*}

Allan, J.F., Batiza, R., Perfit, M.R., Fornari, D.J., and Sack, R.O., 1989. Petrology of lavas from the Lamont seamount chain and adjacent East Pacific Rise, $10^{\circ}$ N. J. Petrol., 30:1245-1298.

Batiza, R., and Niu, Y., 1992. Petrology and magma chamber processes at the East Pacific Rise $\approx 9^{\circ} 30$ N. J. Geophys. Res., 97:6779-6797.

Byerly, G.R., Melson, W.G., Nelen, J.A., and Jarosewich, E., 1976. Abyssal basaltic glasses as indicators of magma compositions. In Mason, B. (Ed.), Mineral Science Investigations, 1974-1975. Smithsonian Contrib. Earth Sci., 19:22-30.

\footnotetext{
Abbreviations for names of organizations and publications in ODP reference lists follow the style given in Chemical Abstracts Service Source Index (published by American Chemical Society).
}

Gladney, E.S., Jones, E.A., Nickell, E.J., and Roelandts, I., 1992. 1988 compilation of elemental concentration data for USGS AGV-1, GSP-1, and G-2. Geostand. Newsl., 16:111-300.

Glascock, M.D., Nabelek, P.I., Weinrich, D.D., and Coveney, R.R., Jr., 1986. Correcting for uranium fission in instrumental neutron activation. $J$. Radioanal. Nucl. Chem., 99:121-131.

Haskin, L.A., Wildeman, T.R., and Haskin, M.A., 1968. An accurate procedure for the determination of the rare earths by neutron activation. $J$. Radioanal. Nucl. Chem., 1:337-348.

Klitgord, K.D., and Mammerickx, J., 1982. Northern East Pacific Rise: magnetic anomaly and bathymetric framework. J. Geophys. Res., $87: 6725-6750$.

Korotev, R.L., 1987. National Bureau of Standards Coal Flyash (SRM1633a) as a multielement standard for instrumental neutron activation analysis. J. Radioanal. Nucl. Chem., 110:159-177.

Landsberger, S., 1986. Spectral interferences from uranium fission in neutron activation analysis. Chem. Geol., 57:415-421.

Landsberger, S., and Simsons, A., 1987. Quantification of uranium, thorium and gadolinium spectral interferences in instrumental neutron activation analysis of samarium. Chem. Geol., 62:223-226.

Langmuir, C.H., Bender, J.F., and Batiza, R., 1986. Petrologic and tectonic segmentation of the East Pacific Rise, $5^{\circ} 30^{\prime}-14^{\circ} 30^{\prime}$. Nature, 322:422-429.

Storms, M.A., Batiza, R., et al., 1993. Proc. ODP, Init. Repts., 142: College Station, TX (Ocean Drilling Program).

Sun, S.-S., and McDonough, W.F., 1989. Chemical and isotopic systematics of oceanic basalts: implications for mantle composition and processes. In Saunders, A.D., and Norry, M.J. (Eds.), Magmatism in the Ocean Basins. Geol. Soc. Spec. Publ. London, 42:313-345.

Date of initial receipt: 12 August 1993

Date of acceptance: 3 November 1993

Ms 142SR-117 